Meta

Journal des traducteurs

Translators' Journal

\title{
Sign Language Interpreting in Sweden
}

\section{Anna-Lena Nilsson}

Volume 42, numéro 3, septembre 1997

L'interprétation en langues des signes

URI : https://id.erudit.org/iderudit/003738ar

DOI : https://doi.org/10.7202/003738ar

Aller au sommaire du numéro

Éditeur(s)

Les Presses de l'Université de Montréal

ISSN

0026-0452 (imprimé)

1492-1421 (numérique)

Découvrir la revue

Citer cet article

Nilsson, A.-L. (1997). Sign Language Interpreting in Sweden. Meta, 42(3),

550-554. https://doi.org/10.7202/003738ar
Résumé de l'article

Cet article évoque certaines des ressemblances et des différences qui caractérisent l'exercice effectué par les interprètes en langue des signes et par les interprètes en langues orales. Il se termine par un bref historique de

l'évolution des services d'interprétation en langue des signes en Suède et donne un aperçu de la situation actuelle. 


\title{
SIGN LANGUAGE INTERPRETING IN SWEDEN ${ }^{\star}$
}

ANNA-LENA NILSSON

Stockholm University, Stockholm, Sweden

\begin{abstract}
Résumé
Cet article évoque certaines des ressemblances et des différences qui caractérisent l'exercice effectué par les interprètes en langue des signes et par les interprètes en langues orales. Il se termine par un bref historique de l'évolution des services d'interprétation en langue des signes en Suède et donne un aperçu de la situation actuelle.
\end{abstract}

\begin{abstract}
Some of the similarities and differences between the work carried out by sign language interpreters and interpreters between spoken languages are discussed. A short description of the historical development of sign language interpreting services in Sweden as well as an outline of the situation today follows.
\end{abstract}

\section{SIMILARITIES}

Working as a sign language interpreter at various international conferences, I have had many interesting discussions with colleagues "in the booths." After a day of watching sign language interpreters working, and maybe also doing relay-interpreting from our spoken interpretation of a signed presentation, they have come to a single conclusion: all interpreters do the same job; we interpret between two languages. In an infinite variety of situations the interpreter receives a message in one language and interprets it into another language, simultaneously or consecutively. Knowledge of languages and cultures are the most important tools of the trade for all interpreters. But being bilingual/bicultural is not necessarily enough to make an interpreter of somebody. The skill of interpreting takes training, talent, and time, to master. The basics of interpreting that have been mentioned in the above apply regardless of what the working languages of the interpreter are.

\section{DIFFERENCES WHEN ONE LANGUAGE IS VISUAL}

One (or more) of the working languages of a sign language interpreter is a visual/ gestural language, i.e. the natural sign language of a country. Signed languages are not visual representations of a country's spoken language. They are full, natural languages in their own right, with a structure of their own. Signed languages make use of all three dimensions of the space in front of the person signing, and movement is an essential part of these languages. These essential aspects of the language are by their very nature difficult to render graphically and/or in print. Even though some writing systems have been constructed, most speakers of signed languages have no means of writing that language. This is partly why interpreters working with signed languages have practically no dictionaries to use in their work. Recently, work has been initiated in several countries, though, with the aim of producing dictionaries using the latest computer technology. There is however a more socio-political reason to the lack of dictionaries. This will be mentioned later. 
With one working language being auditory and the other visual, it is always practically possible to interpret simultaneously. Many hearing persons find it very disturbing when it is totally silent in the room and a deaf person is signing for several minutes. Therefore there is often a more or less overt pressure on us to interpret simultaneously in all situations. Thus, for sign language interpreters working simultaneously is the norm, regardless of whether we interpret at an international conference or in a dialogue between two people e.g. in a police interrogation.

Since signed languages are visual it is not possible for sign language interpreters at a large conference; for example, to be an "impersonal voice" in the ears of those participants in need of interpreting services. When interpreting into sign language we must always be positioned so that everybody who needs our services can see us. Preferably we should be placed close to the speaker, to make it possible for the deaf participant to look at the speaker too, from time to time, and form an opinion of the situation based on that information as well as on what is said.

Recently discussion has also emerged regarding what possible effects there can be on the intonation pattern of simultaneous interpretation when one language is visual. The problem with anomalous prosody in simultaneous interpreting has been discussed among interpreters and teachers of interpreting for a long time (Williams 1995). The issue of the possible effects of language modality on simultaneous interpretation is discussed e.g. in Isham (1994), Isham (1995), Isham \& Lane (1993), and Williams (in press).

\section{DIFFERENCES DUE TO THE FACT THAT ONE LANGUAGE IS A MINORITY LANGUAGE}

Acquiring the necessary fluency in a signed language can pose a problem, if you are not a native speaker. There is no "Deaf-country" which you can visit in order to learn its sign language. Moreover, most countries in the world have traditionally not given official recognition to their national sign language as a language. Research in signed languages was not initiated until the late 1960's, and it is still carried out only in relatively few countries in the world. The knowledge acquired is limited and there have been attempts nade to describe only comparatively few sign languages. Even the sign languages which have been studied for the longest period of time have only been partially described. As a consequence there are hardly any comprehensive dictionaries published for the signed languages of the world. Most countries offer no opportunity to study sign language at an academic level and the pedagogical issues surrounding the recently emerged task of teaching sign language to adult beginners have only begun to be solved. With the lack of knowledge about signed languages, and the small possibilities offered to study them today, even native speakers of the language (e.g. hearing children of deaf parents) have no opportunity to learn anything about their language.

For a language as small as e.g. Swedish Sign Language, there is also a problem due to a lack of qualified interpreters. There are simply not enough native speakers of the language who are interested in, and capable of, becoming simultaneous interpreters. Even though it is often argued that an interpreter working into her/his native language will procluce the most idiomatic interpretation, it is frequently not possible to work in accordance with this belief.

Signed languages have not been regarded as real languages and the speakers of signed languages have not been regarded as equals in society. Deaf people are still frequently regarded as "deaf and dumb." This situation adds extra pressure to the process of simultaneous interpretation as most sign language interpreters will feel a need to make extra certain that what they produce when they interpret is an adequate spoken version of what the deaf person signed. There is a deep affinity between most sign language 
interpreters and deaf people which has its roots in the oppression it is felt that society has subjected speakers of sign language to.

\section{THE DEVELOPMENT OF SIGN LANGUAGE INTERPRETING IN SWEDEN}

In the following section the development of sign language and its situation in Sweden today are described. It must be emphasized, however, that the situation differs from country to country. It is only in relatively few countries in the world, and quite recently, that it has become possible to earn a living as a professional sign language interpreter. More and more countries are now acknowledging sign language and the need for interpreting services for deaf people, and they are now for the first time planning formal education for sign language interpreters.

Sweden holds a very liberal view of a person's right to an interpreter in a number of situations, when that person does not speak Swedish. This view is largely due to the sizeable number of immigrants that have arrived during the last decades. It is estimated that one million people of the approximately eight million inhabitants in Sweden were themselves born in another country, or have at least one parent who was. During the past twentyfive years we have also seen a radical change in Swedish society as to the view of deaf people and their right to interpreting services. The earliest sign language interpreters were friends and relatives of deaf people, but also professionals in the field of deafness e.g. ministers of the deaf. The first mention of deaf people's right to an interpreter, and legislation regarding their right to an interpreter during legal proceedings, dates back to 1947 . Not until 1968 did the Swedish Parliament provide money for interpreting services on an experimental basis, and in 1969 one full-time interpreter was employed. As of 1976 there have been full-time interpreters employed throughout the country, financed by society as part of the public health budget.

Training programs for sign language interpreters have developed constantly over the years. Since the first two-week course in 1969, the basic training for sign language interpreters has expanded to a two-year full time program, with fluency in sign language as an entrance requirement. January 1996 also saw the start of a four-year project with the aim of teaching sign language as well as interpreting to a group of specially selected students. In 1991, responsibility for the training of sign language interpreters was transferred from the Swedish National Board of Education to the Institute for Interpretation and Translation Studies (IITS) at Stockholm University. The decision resulted in the Institute being responsible for the training of all interpreters in Sweden, regardless of working languages and regardless of whether the interpreters were going to work as community interpreters or as conference interpreters. The process of initiating a certification system for sign language interpreters, on par with the existing certification system for interpreters working with immigrants in their contacts with Swedish authorities, has recently begun.

\section{INTERPRETING SERVICES TODAY}

Deaf people in Sweden have been acknowledged as bilingual with a right to be "fluent in their visual/gestual sign language and in the language society surrounds them with - Swedish." (Swedish Parliament, 14 May 1981). As of 1993, the legal right of a deaf person to interpreting services in every day life, free of charge, has been expanded. The situations specifically mentioned in the new law include going to the drugstore, the dentist, the doctor, various contacts with authorities, union meetings, information meetings at work, weddings, funerals and other religious services, leisure activities as well as work and activities in various associations. The law also specifically states that interpreting services should not be restricted to those situations listed. There is no upper limit as to the 
number of hours of interpreting a person is entitled to. When an estimate of the need for interpreters in Sweden was done in 1991 the figures used to calculate the average need of interpreting services were: three hours/week for each deaf person and one interpreter per twelve deaf persons. There are approximately 8,000-12,000 deaf persons in Sweden, and the need was estimated at 750 full-time positions for sign language interpreters. Based on these figures the need is far from met. At the last count (1991) there were approximately 120 interpreters employed full-time by the county councils and approximately another 40 were as educational interpreters. There were also some 300-350 interpreters working on a free-lance basis. The most serious threat to deaf people's legal right to sign language interpreting services today is the serious lack of qualified interpreters throughout the country.

Even though there is no mention of hearing people and their need for interpreting services in their contacts with deaf people a common practice has developed. In many places in Sweden it is perfectly acceptable for e.g. a doctor or a real estate agent to engage an interpreter when they know that the patient/client is deaf. The cost will be defrayed by the county council in these situations as well as in any other situation.

\section{COMMUNITY INTERPRETING}

The interpreting services a deaf person is entitled to in accordance with Swedish law are organized through sign language interpreting units located in approximately 25 cities all over Sweden, and financed by the county councils as part of the public health services. As can be understood from the varying situations where deaf people have a legal right to interpreting services, a sign language interpreter must be prepared to work in practically any situation. Sometimes the topics discussed will be theoretical and highly specialized, and sometimes there may be need for sign language interpreters in very private and emotional situations like child births, divorce proceedings, etc. An advantage of centralized services is that there is a pool of interpreters to choose from, making it easier to send the interpreter(s) best suited for the assignment. Whenever an assignment is estimated to last for more than 1 or 2 hours, or judged to very taxing, the co-ordinator of services can send two or more interpreters. For the interpreters themselves, working with a group of colleagues gives them the opportunity to discuss professional issues frequently. Working in pairs, as happens quite often, adds the extra security of being two persons responsible for the transmission of the message.

\section{EDUCATIONAL INTERPRETING}

There is no interpreting in primary schools in Sweden. Deaf children in need of visual communication attend special schools, where sign language is the language of instruction. Practically all deaf youth go on to secondary education which is specialized as well. Only in exceptional cases are interpreters needed in the secondary education. Every deaf person has the same right as any other citizen to enrol in higher education. In tertiary education, however, deaf students attend the same universities and higher education facilities as other students. When a deaf person is accepted as a student, interpreters must be hired to interpret classes, seminars, student discussion groups, etc. Hiring interpreters is the responsibility of the school/university in question and the services are free of charge for the student. Today there are some 50 interpreters employed all over the country as full-time interpreters in tertiary education. Educational interpreters usually work in pairs, except in situations where the students work mainly on their own and get brief instructions from the teacher. Besides interpreting, educational interpreters have part of their working hours scheduled for preparation. They frequently have to study textbooks and other material before interpreting e.g. a lecture physiognomy. 


\section{CONFERENCE INTERPRETING}

For a deaf person to make a career or be active in an association in today's society, attending various conferences is a necessity. Sweden entering the European Union has generated a number of meetings and conferences as well. Sweden is a small country with a small national language and as soon as sign language interpreting is needed at international conferences Swedish sign language interpreters will therefore have to work into/from yet another language (usually English). There are no special training programs for sign language interpreters working at international conferences. When a Swedish deaf person gives a presentation in Swedish Sign Language, there is need for a Swedish sign language interpreter with enough knowledge and skills in English, for example, to do simultaneous interpretation into English instead of into Swedish. Since each country has its own sign language, just as it has its own spoken language, a native speaker of English (e.g. an American sign language interpreter) will usually not be of any use, as she or he is not likely to understand Swedish Sign Language.

Another problem regarding presentations in sign language at conferences etc. stems from the fact that the presenters usually do not write their manuscript in sign language, but in Swedish or English. To produce an adequate simultaneous interpretation of an academic presentation with its highly specialized content and vocabulary, the interpreter needs to prepare thoroughly. To get presenters' papers well in advance of a conference in order for interpreters to be able to prepare is usually difficult. For sign language interpreters, there is an added problem - even if we do get a deaf presenter's paper in advance, what is printed there is not what the speaker will say. What is printed is a translation of the presentation into English, Swedish, or another written language. Moreover, that translation may sometimes have been done by somebody other than the presenter. On a number of occasions, Swedish sign language interpreters and deaf Swedish presenters have worked together in a very fruitful manner. The presenter and the interpreter(s) have met and worked together beforehand, rehearing the presentation and the interpretation in order to find where potential difficulties are and finding solutions. The result has been very encouraging and this approach has more or less developed into common practice.

\section{THE FUTURE}

With the transfer of the responsibility of training sign language interpreters to the Institute for Interpretation and Translation Studies, a more integrated view on issues regarding interpreting has emerged. We are hoping to be able to use our common knowledge and our experiences from various aspects of interpreting to develop both the training and practice of all kinds of interpreters.

\footnotetext{
Note

* I would like to thank my colleagues Inger Ahlgren and Brita Bergman for valuable comments on earlier versions of this article.
}

\section{REFERENCES}

ISHAM, W. P. (1994): "Memory for Sentence form after Simultaneous Interpretation: Evidence both for and against Deverbalization", Lambert, S. \& B. Moser-Mercer (Eds), Bridging the Gap, Amsterdam, Benjamins, pp. 191-211.

ISHAM, W. P. (1995): "On the Relevance of Signed Languages to Research in Interpretation", Target, 7 (1), pp. 135-149.

ISHAM, W. P. \& H. LANE (1993): "Simultaneous Interpretation and the Recall of Source-language Sentences", Language and Cognitive Processes, 8, pp. 241-264.

WILLIAMS, S. (1995): "Observations on Anomalous Stress in Interpreting", The Translator, 1 (1), Manchester, St Jerome Publishing, pp. 47-64.

WILLIAMS, S. (in press): "Prosody and Comprehension in Simultaneous Interpreting", Paper presented at ASLA '95 Symposium om sprakforstaelse, Lund, 9-11 November 1995, To appear in ASLA report 1996. 